\title{
Establishment of a Protocol for in vitro Seed Germination and Callus Formation of Ficus religiosa L., an Important Medicinal Plant
}

\author{
Mohsen Hesami ${ }^{1,{ }^{*}}$, Mohammad Hosein Daneshvar ${ }^{2}$ and Mohsen Yoosefzadeh-Najafabadi ${ }^{1}$ \\ ${ }^{1}$ Department of Horticulture Science, University of Tehran, Karaj, Iran \\ ${ }^{2}$ Department of Horticulture Science, Ramin University of Agriculture and Natural Resources, Khuzestan, Iran \\ "Corresponding author: Department of Horticulture Science, University of Tehran, Karaj, Iran, Email: mohsenhessami33@ut.ac.ir
}

Received 2017 March 12; Revised 2017 October 14; Accepted 2017 October 24.

\begin{abstract}
Background: Ficus religiosa is known as a pure source in traditional medicine for the treatment of diabetes, asthma, diarrhea, gastric problems, epilepsy, sexual, infectious, and inflammatory disorders. Despite the fact that many studies have authorized its traditional medicinal uses, yet these utilized raw extracts have not been yet characterized. Therefore, there is a necessity for standardizing its phytochemical features and recognizing bioactivity, guided by bioactive metabolites.

Objectives: In this study, the effect of light and dark condition, different strengths of Murashige and Skoog (MS) medium, and their interactions on seed germination and the effect of plant growth regulators on callogenesis of $F$. religiosa via leaf, petiole, root, and internode explants were investigated.

Results: The results demonstrated the highest seed germination percentage was achieved at one-tenth strength of MS medium under the light condition. Also, the highest callus fresh weight was obtained from media supplemented with $0.5 \mathrm{mg} / \mathrm{L} 2,4-$ dichlorophenoxyacetic acid (2, 4-D) and $0.05 \mathrm{mg} / \mathrm{L}$ 6- benzyl amino purine (BAP) in all explants. The MS medium containing indole3-butyric acid (IBA) produced greenish and compact calli while yellowish and compact calli was achieved in $\alpha$-naphthalene acetic acid (NAA) and finally 2,4-D produced yellow-brownish calli.

Conclusions: To the best of the author's knowledge, this study was the first report of seed germination and callus induction through immature explants of F. religiosa. The seed germination and callogenesis system established in this study could be applied in the future for the enrichment of certain secondary metabolites as well as the production of new secondary metabolites, with the purpose of understanding and use of medicinal properties for this valuable germplasm.
\end{abstract}

Keywords: Seed Germination, Callus Induction, Plant Growth Regulator, Ficus religiosa

\section{Background}

Ficus religiosa $\mathrm{L}$. is known as an important biofuel wood, and medicinal tree that belongs to the family of Moraceae and it distributes in the wild or cultivated types throughout India, Pakistan, Bangladesh, Nepal, and Southern Iran. Ficus religiosa has intense religious holdings among Buddhists and Hindus $(1,2)$. It has a tipped, leathery, long petiolate, and heart-shaped leaves. It is also known as a popular tropical shade tree due to its easy adaptability to various soil conditions and well-formed shape. Ficus religiosa L. also has an ornamental value and is commonly employed as a roadside tree. Its tender leaf buds and fruits are sometimes consumed at the times of famine. Birds also eagerly eat the fruits (3). Furthermore, F. religiosa L. has a significant medicinal value (4). For instance, the bark extract is employed for treating various diseases, such as inflammations, glandular swelling, di- abetes, stomatitis, asthma, wound healing, and skin diseases. Leaf extracts are applied for treating constipation, and ear problems (5), and root barks have a positive effect in cleaning ulcers and leucorrhoea (6). Moreover, stem barks have been recently reported to have a remarkable acetylcholinesterase inhibitory activity that is useful for treating Alzheimer's disease (7). There are some identified secondary metabolites, including methyl oleanolate, caffeic acid, stigmasterol, bergenin, lupin 3-one, lanosterol, noctacosanol, flavonoids, amides, and $\beta$-sitosterol, which are responsible for different biological activities (8). However, some of the secondary metabolites from F. religiosa have remained unexplored (4). The isolation and characterization of such metabolites are often conducted through naturally occurring sources. Such processes are time and labor consuming and affected by different environmental conditions. Hence, there is a dire need for providing an alternative method to isolate secondary metabo- 
lites of this valuable medicinal germplasm (9). In the mid 1960 s, the cell culture of the plant was introduced as a useful tool for studying and producing secondary metabolites of the plant. Some of the important secondary metabolites, employed in pharmaceuticals, cosmetics, and food industry, have been produced through cell, callus, root, and shoot cultures of the plant $(4,10,11)$. The advantages of direct manipulation of the cell, tissue, and organ cultures are more than the traditional isolation of secondary metabolites. It has been reported that such manipulations increase the production of secondary metabolites in many species (12). The rate success amongst in vitro culture of woody plants, especially old age plants, has remained a challenging task, despite great development in plant tissue culture techniques $(9,12)$. The age of the explant could play a significant role in plant tissue culture, and physiologically younger segments had a better performance than the older one (13). One way to eliminate the effect of plant's age is to use different parts of in vitro-grown seedlings (14). Moreover, the response of plant growth regulators that change during plant tissue culture can be varied from species to species and also this response depends on the ability of tissues to respond and the types of plant growth regulators (15). For instance, auxins and cytokinins play an essential role in plant tissue culture in the procedures for plant propagation, such as shoots development and stimulation, and callus formation and induction (16).

\section{Objectives}

The present study investigated the optimized conditions for in vitro seed germination and callus formation via different parts of in vitro-grown seedlings. The callus culture generated in this study could be easily utilized for better screening, isolation, and characterization of different secondary metabolites of $F$. religiosa for future applications in pharmaceuticals.

\section{Methods}

The fruits of F. religiosa were collected from a 45- to 50year-old $F$. religiosa mother plants that were grown on the campus of Ramin Agriculture and Natural Resources University, Khuzestan, Iran. The fruits were washed for $30 \mathrm{~min}$ utes under tap water and rinsed 5 to 6 times. Then another washing process was applied using a liquid soap solution followed by rinsing with tap water again. Further surface sterilization treatment was carried out in a laminar air flow chamber. The surface of the seeds was sterilized for 10 seconds with 70\% aqueous ethanol, and dipped in $10 \%$ bleach solution (with $5 \%$ active $\mathrm{NaOCl}$ ) for 5 minutes and finally washed 3 times with sterilized distilled water. A factorial experiment was set to estimate the effect of different strengths of MS medium (one-tenth strength of MS, half strength of MS, and full strength of MS) and light condition (24-hour light and dark) on in vitro seed germination of $F$. religiosa. Media were supplemented with $3 \%$ w/v sucrose, $\mathrm{pH}$ was adjusted to 5.8 with $1 \mathrm{~N} \mathrm{HCl}$ or $\mathrm{KOH}$, solidified with $0.6 \%$ agar and autoclaved at $121^{\circ} \mathrm{C}$ for 15 to 20 minutes at $15 \mathrm{psi}$ or one bar pressure, and poured into the culture bottles ( $2 \mathrm{~cm}$ in diameter and $15 \mathrm{~cm}$ in height). All cultures were kept in a culture room at $26 \pm 2^{\circ} \mathrm{C}$ under light $\left(63 \mu \mathrm{mol} \mathrm{m}^{-2} \mathrm{~s}^{-1}\right)$ or dark conditions. The seeds were germinated after 14 days (Figure 1A), and seedlings from in vitro germinated seeds were utilized as the source of explants for the next experiment. The cultures were observed periodically, and germinated seeds were counted as well. The seeds representing radicle protrusion were assumed germinated. At the end of this experiment after 14 days, percentage of seed germination was calculated. Explants with 0.5 to $1.0 \mathrm{~cm}$ of length, from the leaf, petiole, internode, and root of 1-month-old seedlings (Figure 1B) were cultured in MS medium consisting of various concentrations of plant growth regulators for callus induction (Table 1). The cultures were inoculated at $26 \pm 2^{\circ} \mathrm{C}$ in darkness. The frequency (\%) of callus formation and its fresh weight were recorded after 4 weeks of culture. The experiments were conducted with a Completely Randomized Design (CRD). There were 10 replicates per treatment, and each treatment was repeated in 3 sets. Data analysis was set up through Analysis of Variance (ANOVA) followed by Duncan's multiple range test. Data were analyzed by SAS version 9.3.

\section{Results}

According to the current results, one-tenth strength MS medium and light (83.33\%) had the highest seed germination percentage among other treatments while it did not have a significant difference in the half-strength MS medium and light condition (Table 1).

Generally, the regression analysis indicated that there was a decreasing polynomial trend from 0.1 strength MS to full strength MS in both dark and light conditions and the light condition had a higher R2 than the dark condition (Figure 2). The effect of different concentrations of plant growth regulators on callus induction from $F$. religiosa was studied in leaf, petiole, internode, and root explants that were cultured in MS medium (Table 2). The explants did not show any response to control treatment (MS medium without any PGRs) and initially the cut ends, and later, the whole explant blackened because of phenolic exudation, and finally the explants lead to death within 10 

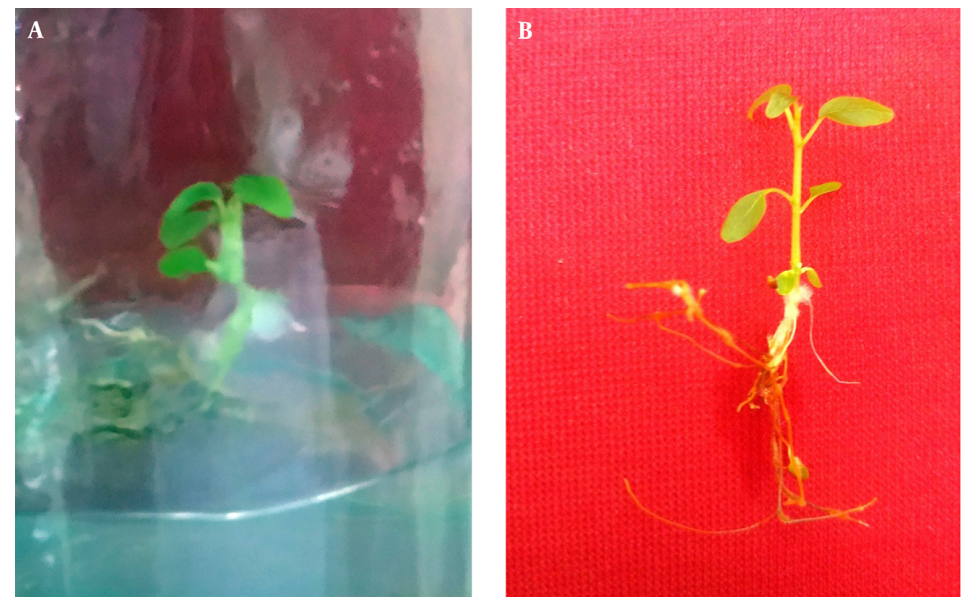

Figure 1. In Vitro Seed Germination of Ficus religiosa L. After (A) 14 and (B) 30 Days

\begin{tabular}{|c|c|}
\hline Treatment & Seed Germination, \% \\
\hline \multicolumn{2}{|l|}{ Light conditions } \\
\hline Light & $67.778 \mathrm{a}$ \\
\hline Darkness & $55.556 \mathrm{~b}$ \\
\hline \multicolumn{2}{|l|}{ Different strength MS medium } \\
\hline 0.1 strength MS & $78.333 \mathrm{a}$ \\
\hline 0.5 strength MS & $68.333 \mathrm{~b}$ \\
\hline Full strength MS & $38.333 \mathrm{c}$ \\
\hline \multicolumn{2}{|c|}{ Different strength MS $\times$ Light conditions } \\
\hline 0.1 strength MS $\times$ Light & $83.333 \mathrm{a}$ \\
\hline 0.1 strength $\mathrm{MS} \times$ Darkness & $73.333 \mathrm{~b}$ \\
\hline 0.5 strength $\mathrm{MS} \times$ Light & $76.667 \mathrm{ab}$ \\
\hline 0.5 strength MS $\times$ Darkness & $60.000 \mathrm{c}$ \\
\hline Full strength MS $\times$ Light & $43.333 \mathrm{~d}$ \\
\hline Full strength MS $\times$ Darkness & $33.333 \mathrm{e}$ \\
\hline
\end{tabular}

${ }^{\mathrm{a}}$ Means in each column followed by same letters at superscript are not significantly different according to DMRT at $\mathrm{P}<0.05$.

days of culture. After 7 days of culture, an initial response, such as curl and swelling, of explants was observed. After 2 weeks of culture, the callus induction was begun from the cut margins of explants that were cultured in MS medium containing with 2, 4-D, IBA and NAA along with BAP, in the absence of light (Table 2). A wide range of callus induction frequencies were observed at various concentrations of PGRs, and also a high callus induction was obtained in 2,4-D, NAA, and IBA along with BAP, respectively. However, there was no callus formation observed at low concentra- tions of IBA ( $0.5 \mathrm{mg} / \mathrm{L})$ along with BAP $(0.05 \mathrm{mg} / \mathrm{L})$. According to the regression analyses in Figure 3, the highest fresh weight was obtained from $0.5 \mathrm{mg} / \mathrm{L}$ 2,4-D and $0.05 \mathrm{mg} / \mathrm{L}$ BAP in explants, and also 2, 4-D produced yellow-brownish friable callus from all explants (Figure 4). Based on Figure 3, by increase in the concentration of 2,4-D, the callus induction decreased significantly. However, Figure 5 indicated that increasing in NAA concentration induced more callus formation and the highest callus formation was achived in explants derived from leafs at high concentrations of NAA. Same as NAA, callus formation had an incresing polynomial trend with incresing concentration of IBA (Figure 6).

Furthermore, MS medium consisting of IBA produced greenish compact calli from explants while NAA produced yellowish compact calli (Figure 4).

\section{Discussion}

The overall objective of the first experiment was to study the effect of light and dark condition with various strengths of MS medium in in vitro seed germination and to investigate callus formation from the leaf, petiole, internode, and root segments of $F$. religiosa. The rate of $F$. religiosa seed germination increased exponentially under the light condition. Despite that there are no reports on in vitro seed germination of F. religiosa, the effect of light on increasing seed germination of other plants has been investigated in many studies $(17,18)$. There are also many studies that have proved the effect of higher light intensity in promoting seed germination (19). Similar to the current results, Wall et al. (20) indicated that seed germination was higher under the light condition when compared with the dark condition in Pyxidanthera brevifolia. Further- 


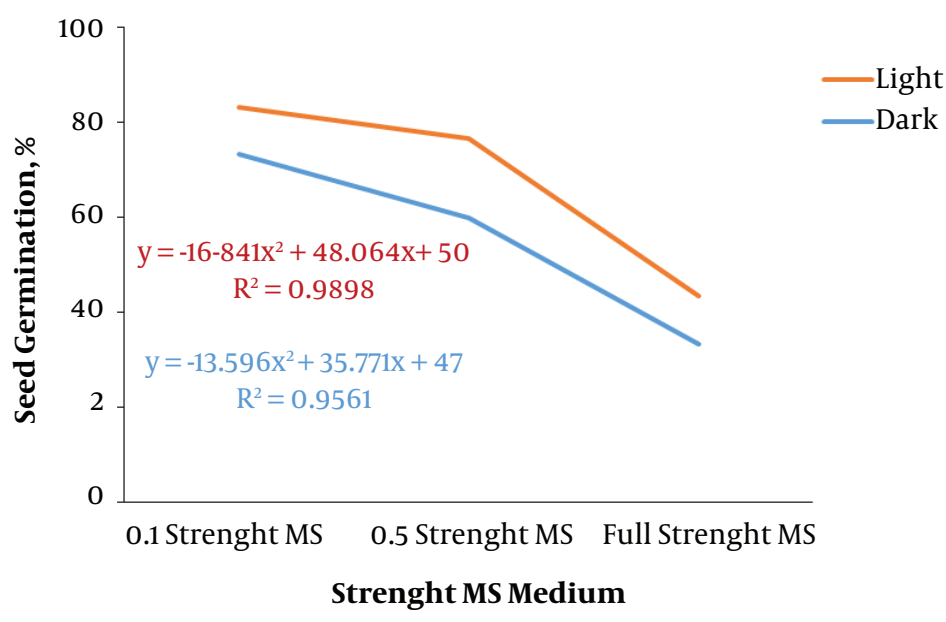

Figure 2. Interaction of Different Strengths of MS Medium and Light or Dark Conditions on Seed Germination of Ficus religiosa

Table 2. Effect of 2,4-D, NAA or IBA in Combination with BAP in MS Medium on Callus Induction of F. religiosa from Immature Explants ${ }^{\mathrm{a}}$

\begin{tabular}{|c|c|c|c|c|c|c|c|c|c|c|c|}
\hline \multirow{2}{*}{$\begin{array}{l}\text { Plant Growth } \\
\text { Regulator, mg/L } \\
\text { 2,4-D }\end{array}$} & \multirow[b]{2}{*}{ NAA } & \multirow[b]{2}{*}{ IBA } & \multirow[b]{2}{*}{ BAP } & \multicolumn{2}{|c|}{ Leaf } & \multicolumn{2}{|c|}{ Petiole } & \multicolumn{2}{|c|}{ Internode } & \multicolumn{2}{|c|}{ Root } \\
\hline & & & & $\begin{array}{c}\text { Callus } \\
\text { Formation } \\
\text { Frequency (\%) }\end{array}$ & $\begin{array}{l}\text { Fresh Weight of } \\
\text { Callus, } \mathrm{g}\end{array}$ & $\begin{array}{c}\text { Callus } \\
\text { Formation } \\
\text { Frequency(\%) }\end{array}$ & $\begin{array}{l}\text { Fresh Weight of } \\
\text { Callus, } \mathrm{g}\end{array}$ & $\begin{array}{c}\text { Callus } \\
\text { Formation } \\
\text { Frequency (\%) }\end{array}$ & $\begin{array}{l}\text { Fresh Weight of } \\
\text { Callus, } g\end{array}$ & $\begin{array}{c}\text { Callus } \\
\text { Formation } \\
\text { Frequency(\%) }\end{array}$ & $\begin{array}{l}\text { Fresh Weight of } \\
\text { Callus, } \mathrm{g}\end{array}$ \\
\hline . & . & . & . & $0.00 \mathrm{f}$ & $0.00 \mathrm{f}$ & $0.00 \mathrm{e}$ & $0.00 \mathrm{~h}$ & $0.00 \mathrm{~d}$ & $0.00 \mathrm{~h}$ & $0.00 \mathrm{~d}$ & $0.00 \mathrm{f}$ \\
\hline 0.5 & . & . & 0.05 & $100.00 \mathrm{a}$ & $2.90 \mathrm{a}$ & $100.00 \mathrm{a}$ & $2.08 \mathrm{a}$ & $100.00 \mathrm{a}$ & $2.28 \mathrm{a}$ & $100.00 \mathrm{a}$ & $2.33 \mathrm{a}$ \\
\hline 1.0 & . & - & 0.1 & $93.33 \mathrm{ab}$ & $0.89 \mathrm{c}$ & $90.00 \mathrm{~b}$ & $1.10 \mathrm{c}$ & $96.67 \mathrm{a}$ & $0.80 \mathrm{c}$ & $100.00 \mathrm{a}$ & $1.03 \mathrm{c}$ \\
\hline 1.5 & . & . & 0.15 & $83.33 \mathrm{C}$ & $0.73 \mathrm{~d}$ & $53.33 \mathrm{c}$ & $0.52 \mathrm{f}$ & $43.33 \mathrm{c}$ & $0.35 \mathrm{f}$ & $53.33 \mathrm{c}$ & $0.72 \mathrm{~d}$ \\
\hline . & 0.5 & . & 0.05 & $33.33 \mathrm{e}$ & $0.72 \mathrm{~d}$ & $83.33 \mathrm{~b}$ & $0.66 \mathrm{e}$ & $83.33 \mathrm{~b}$ & $0.53 \mathrm{e}$ & $96.67 \mathrm{a}$ & $0.72 \mathrm{~d}$ \\
\hline . & 1.0 & . & 0.1 & $86.67 \mathrm{bc}$ & $0.95 \mathrm{c}$ & $90.00 \mathrm{~b}$ & $0.75 \mathrm{e}$ & 93.33 a & $0.62 \mathrm{~d}$ & $100.00 \mathrm{a}$ & $1.03 \mathrm{c}$ \\
\hline . & 1.5 & . & 0.15 & $100.00 \mathrm{a}$ & $2.89 \mathrm{a}$ & $100.00 \mathrm{a}$ & $1.44 \mathrm{~b}$ & $100.00 \mathrm{a}$ & $1.06 \mathrm{~b}$ & $100.00 \mathrm{a}$ & $1.16 \mathrm{~b}$ \\
\hline . & . & 0.5 & 0.05 & $0.00 \mathrm{f}$ & $0.00 \mathrm{f}$ & $0.00 \mathrm{e}$ & $0.00 \mathrm{~h}$ & $0.00 \mathrm{~d}$ & $0.00 \mathrm{~h}$ & $0.00 \mathrm{~d}$ & $0.00 \mathrm{f}$ \\
\hline . & . & 1.0 & 0.1 & $56.67 \mathrm{~d}$ & $0.14 \mathrm{e}$ & $26.67 \mathrm{~d}$ & $0.14 \mathrm{~g}$ & $36.67 \mathrm{c}$ & $0.19 \mathrm{~g}$ & $50.00 \mathrm{c}$ & $0.20 \mathrm{e}$ \\
\hline . & . & 1.5 & 0.15 & $93.33 \mathrm{ab}$ & $1.27 \mathrm{~b}$ & $90.00 \mathrm{~b}$ & $0.97 \mathrm{~d}$ & $83.33 \mathrm{~b}$ & $0.54 \mathrm{e}$ & $83.33 \mathrm{~b}$ & $0.94 \mathrm{c}$ \\
\hline
\end{tabular}

${ }^{\mathrm{a}}$ Means in each column followed by same letters at superscript are not significantly different according to DMRT at $\mathrm{P}<0.05$.

more, Oh et al. (21) elucidated that light could activate the degradation of PIL5 protein to induce seed germination via gibberellic acid in Arabidopsis. Similar effects of various strengths of MS medium on seed germination have been described for various species $(22,23)$. Martendal et al. (24) applied water-agar medium in order to obtain the highest germination frequency for Byrsonima cydoniifolia. Since the previous reports proved the inhibitory nature of MS medium on seed germination of Aconitum heterophyllum, seed germination occurred on water-agar medium (25). Furthermore, the 0 and $\frac{1}{2}$ strength of MS media in comparison with full strength MS medium, produced a higher seed germination rate in Rauvolfia serpentina (26). In another report, Samuel et al. (27) indicated that the reduction of full Strength MS medium to half strength MS medium was adequate for enhancing the seed germination frequency of Givotia rottleriformis. When embryos are autotrophic, seed germination might occur in media without any nutritional elements and sucrose, by eliminating its supplemental energy source (24). On the other hand, full MS medium caused delay in seed germination due to high nutrition concentrations that were above the threshold level for seed germination (27). However, in other studies conducted by Solanki and Siwach (28) and Hesami and Daneshvar (11), it became clear that the response of seeds to various salt concentrations were different from one species to another species. Overall, seed germination rate was a paramount element in developing in vitro tissue culture, especially in producing a uniform set of seedlings.

In the second experiment, the effect of various concentrations of PGRs on callus formation from 4 different explants of $F$. religiosa was investigated. The plant growth regulators played an important role in callogenesis re- 


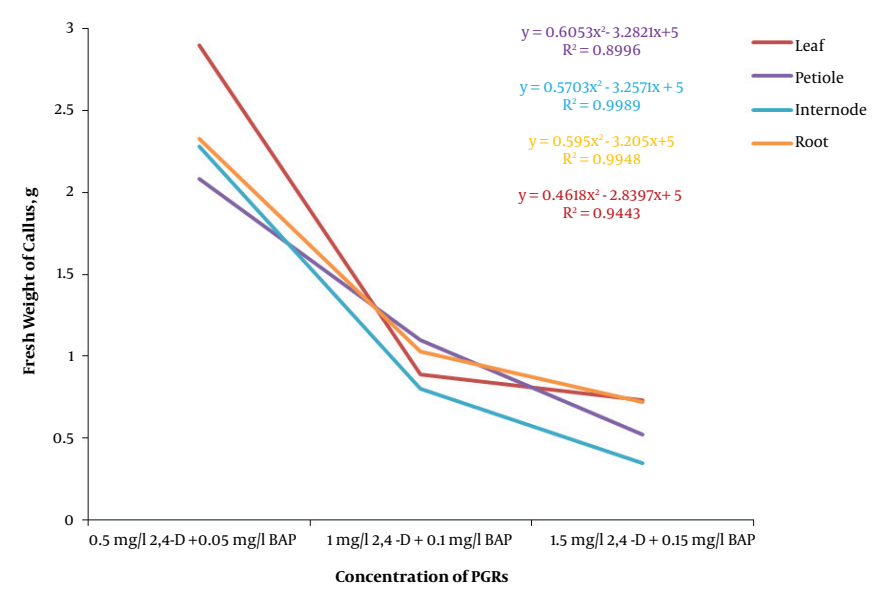

Figure 3. The Effect of Different Concentrations of 2,4-D in Combination with BAP on Callus Fresh Weight in Ficus religiosa

Figure 4. Callus formation from seedling derived leaf, petiole, internode and root segments of Ficus religiosa L.
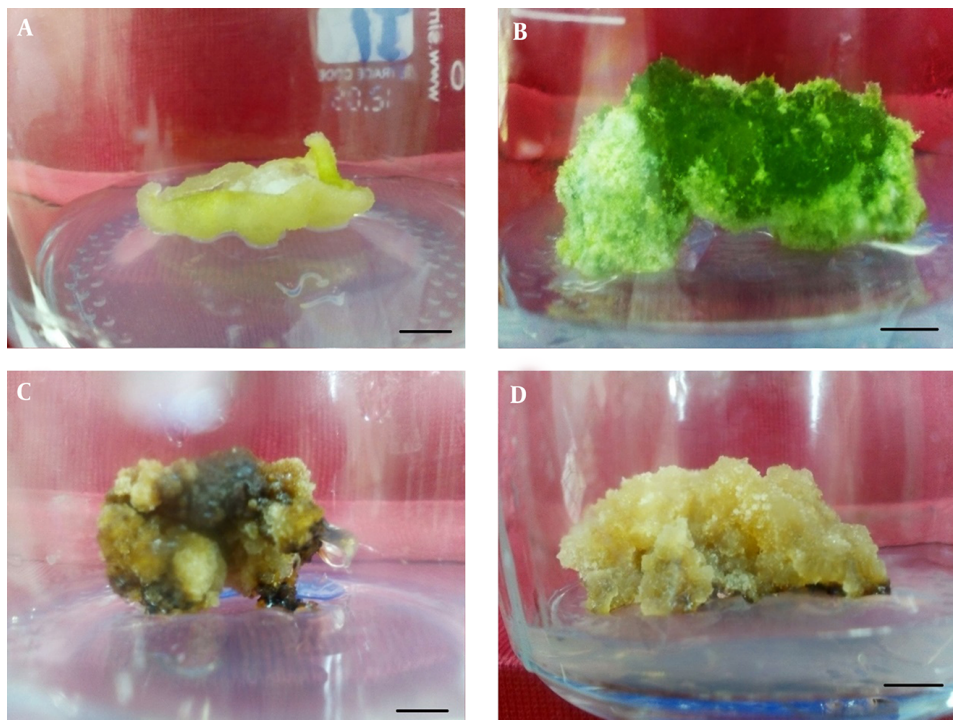

A, Yellowish and compact callus induction on MS $+1.5 \mathrm{mg} / \mathrm{L}$ NAA $+0.15 \mathrm{mg} / \mathrm{L}$ BAP derived from root segments; B, Greenish and compact callus induction on MS + 1.5 mg/L IBA + $0.15 \mathrm{mg} / \mathrm{l}$ BAP derived from leaf segments; C, Yellow-brownish and friable callus induction on MS + 0.5 mg/L 2,4-D + 0.05 mg/L BAP derived from internode segments; D, Yellowish and compact callus induction on MS $+1.5 \mathrm{mg} / \mathrm{L} \mathrm{NAA}+0.15 \mathrm{mg} / \mathrm{L}$ BAP derived from leaf segments, $\mathrm{bar}=0.5 \mathrm{~cm}$.

sponse under in vitro conditions. Many studies proved the positive effect of 2,4-D and NAA in callus induction (14, 29). According to the current results, 2,4-D and NAA along with BA had the highest callus formation frequency among other Auxins, which is in line with the study of Siwach et al. (9), which indicated that MS medium containing 0.5 and $1.0 \mathrm{mg} / \mathrm{L}$ 2,4-D produced acceptable callus formation from nodal, internodal, and shoot apices explants of $F$. religiosa. Also, Narayan and Jaiswal (30) reported that the highest callus formation from leaf explant of $F$. religiosa was achieved on MS medium supplemented with $0.5 \mathrm{mg} / \mathrm{L}$ NAA plus $1.0 \mathrm{mg} / \mathrm{L}$ BAP. Moreover, Su et al. (31) indicated that a high ratio of auxin/cytokinin is critical for callus formation. 2,4-D acts as herbicide, and callus formation could be limited to a high concentration of this auxin (14). However, Parasharami et al. (32) reported that MS medium consisting of $2.4 \mathrm{mg} / \mathrm{L} 2,4-\mathrm{D}$ plus $1.0 \mathrm{mg} / \mathrm{L} \mathrm{BA}$ was the best treatment for callus induction from fruit segments of F. reli- 


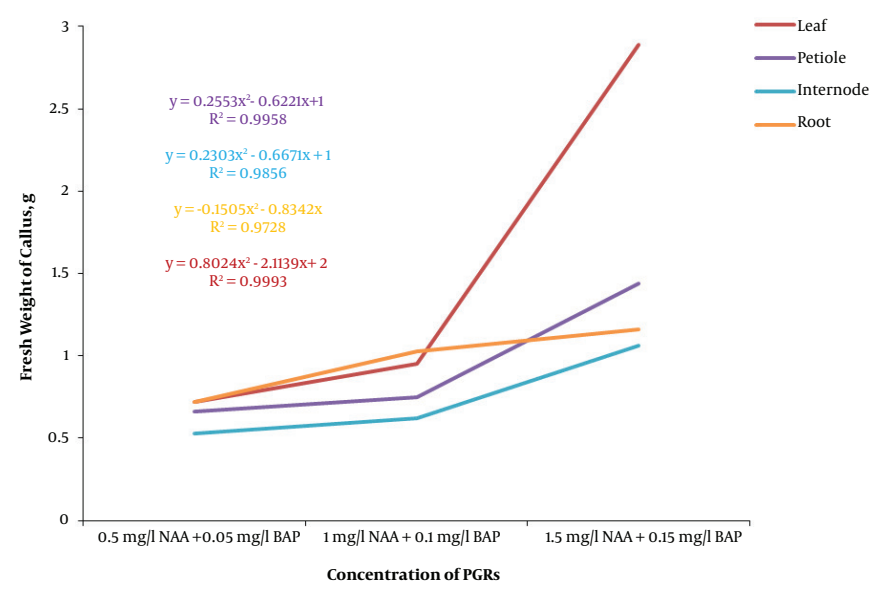

Figure 5. The Effect of Different Concentrations of NAA in Combination with BAP on Callus Fresh Weight in Ficus religiosa

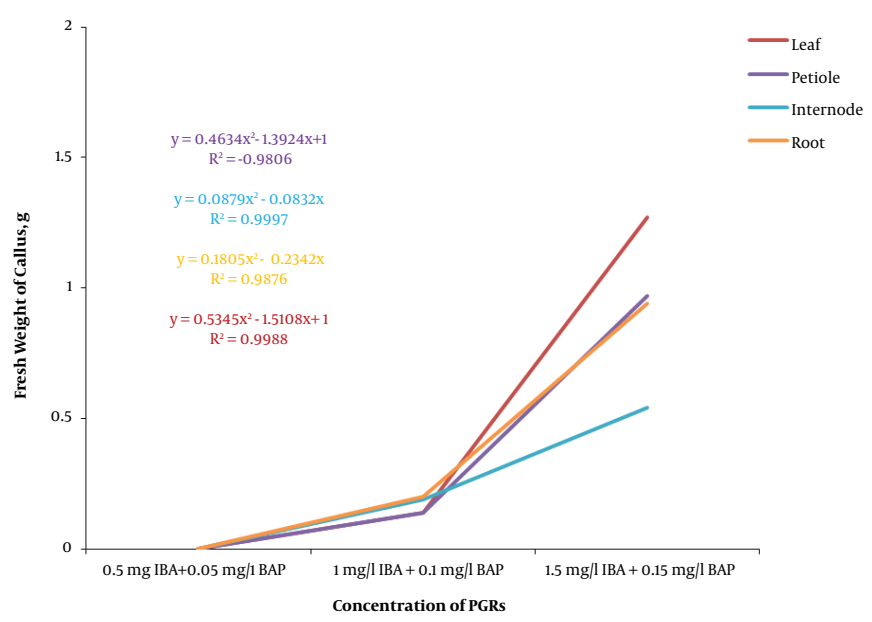

Figure 6. The Effect of Different Concentrations of IBA in Combination with BAP on Callus Fresh Weight in Ficus religiosa

giosa. In the current study, various types of callus were obtained from various concentrations of PGRs. Also, 2, 4-D treatment produced a friable callus, and according to previous results, the best type of callus for suspension culture and cell culture is the friable one (33). Calli usually have 2 types, including compact and friable. These types may be modified by genetic, epigenetic, and culture changes. It is also feasible to obtain various calli types from the same explants (14). Likewise, Garcia et al. (34) indicated that MS medium containing NAA, 2,4-D, and Picloram (PIC) produced friable and compact calli from the leaf, nodal, and internodal segments of Passiflora suberosa. Karami et al. (35) concluded that various calli types from Elaeagnus an- gustifolia obtained from different concentrations of PGRs. In contrast, callus morphology in Hildegardia populifolia was similar under different growth regulators (36).

\subsection{Conclusions}

This is the first protocol for in vitro seed germination and callus induction from immature explants of F. religiosa. The present study provided a reliable method for forming callus via leaf, petiole, internode, and root explants. A suitable calli response was obtained in the MS medium supplemented with 2,4 -D along with BA in all explants. Since friable callus has a significant impact on suspension and cell cultures, this treatment produced the 
highest friable callus among other treatments. There are limited reports on the secondary metabolites of F. religiosa, thus this protocol can be employ as an alternative source of isolation, identification, and characterization of secondary metabolites at the commercial level. Further studies could be conducted for increasing secondary metabolites and identifying novel approaches in order to utilize this plant for medicinal aims.

\section{Acknowledgments}

None.

\section{Footnotes}

Authors' Contribution: Mohsen Hesami conducted the research and wrote the paper; Mohammad Hosein Daneshvar designed the research; Mohsen YoosefzadehNajafabadi performed the data analysis and edited the paper.

Conflict of Interest: The authors declare that they had no conflicts of interest.

Funding/Support: This article was self-funded by the authors and had not received any outside support.

\section{References}

1. Salmi MS, Hesami M. Time of collection, cutting ages, auxin types and concentrations influence rooting Ficus religiosa stem cuttings. J Appl Environ Biol Sci. 2016;6(1):124-32.

2. Hesami M, Daneshvar MH, Lotfi A. In vitro shoot proliferation through cotyledonary node and shoot tip explants of Ficus religiosa L. Plant Tissue Culture Biotechnol. 2017;27(1):85. doi: 10.3329/ptcb.v27i1.35017.

3. Siwach P, Gill AR. Micropropagation of Ficus religiosa L. via leaf explants and comparative evaluation of acetylcholinesterase inhibitory activity in the micropropagated and conventionally grown plants. 3 Biotech. 2014;4(5):477-91. doi: 10.1007/s13205-013-0175-8. [PubMed: 28324379].

4. Singh D, Singh B, Goel RK. Traditional uses, phytochemistry and pharmacology of Ficus religiosa: a review. J Ethnopharmacol. 2011;134(3):565-83. doi: 10.1016/j.jep.2011.01.046. [PubMed: 21296646].

5. Ghosh M, Civra A, Ritta M, Cagno V, Mavuduru SG, Awasthi P, et al. Ficus religiosa L. bark extracts inhibit infection by herpes simplex virus type 2 in vitro. Arch Virol. 2016;161(12):3509-14. doi: 10.1007/s00705016-3032-3. [PubMed: 27581805].

6. Pawar PL, Nabar BM. Effect of plant extracts formulated in different ointment bases on MDR strains. Indian J Pharm Sci.2010;72(3):397-401. doi: 10.4103/0250-474X.70494. [PubMed: 21188057].

7. Vinutha B, Prashanth D, Salma K, Sreeja SL, Pratiti D, Padmaja $\mathrm{R}$, et al. Screening of selected Indian medicinal plants for acetylcholinesterase inhibitory activity. J Ethnopharmacol. 2007;109(2):35963. doi:10.1016/j.jep.2006.06.014. [PubMed:16950584].

8. Bhangale JO, Acharya NS, Acharya SR. Protective effect of Ficus religiosa (L.) against 3-nitropropionic acid induced Huntington disease. Orient Pharm Exp Med. 2016;16(3):165-74. doi: 10.1007/s13596-016-02377.

9. Siwach P, Gill AR, Kumari K. Effect of season, explants, growth regulators and sugar level on induction and long term maintenance of callus cultures of Ficus religiosa L. Afr J Biotechnol. 2011;10(24):4879-86.
10. Cagno V, Civra A, Kumar R, Pradhan S, Donalisio M, Sinha BN, et al. Ficus religiosa L. bark extracts inhibit human rhinovirus and respiratory syncytial virus infection in vitro. J Ethnopharmacol. 2015;176:2527. doi: 10.1016/j.jep.2015.10.042. [PubMed: 26528588].

11. Hesami M, Daneshvar MH. Development of a regeneration protocol through indirect organogenesis in chenopodium quinoa willd. Indo Am J Agric Vet Sci. 2016;4(2):25-32.

12. Marsik P, Sisa M, Lacina O, Motkova K, Langhansova L, Rezek J, et al. Metabolism of ibuprofen in higher plants: A model Arabidopsis thaliana cell suspension culture system. Environ Pollut. 2017;220(Pt A):383-92. doi: 10.1016/j.envpol.2016.09.074. [PubMed: 27720542].

13. Lamas DL, Yeannes MI, Massa AE. Alkaline trypsin from the viscera and heads of Engraulis anchoita : partial purification and characterization. BioTechnologia. 2017;2:103-12. doi: 10.5114/bta.2017.68309.

14. Bhojwani SS, Dantu PK. Micropropagation. In: Bhojwani SS, Dantu PK, editors. Plant Tissue Culture: An Introductory Text. New Delhi: Springer; 2013. p. 245-74.

15. Singh CK, Raj SR, Jaiswal PS, Patil VR, Punwar BS, Chavda JC, et al. Effect of plant growth regulators on in vitro plant regeneration of sandalwood (Santalum album L.) via organogenesis. Agroforestry Systems. 2015;90(2):281-8. doi: 10.1007/s10457-015-9853-3.

16. Hesamia M, Naderia R, Yoosefzadeh-Najafabadia M, Rahmatib M. Data-driven modeling in plant tissue culture. J Appl Environ Biol Sci. 2017;7(8):37-44.

17. Khan MA, Abbasi BH, Ahmed N, Ali H. Effects of light regimes on in vitro seed germination and silymarin content in Silybum marianum. Indust Crops Prod. 2013;46:105-10. doi: 10.1016/j.indcrop.2012.12.035.

18. Yang G, Shen X, Jackson R, Lu Z. Factors affecting'in vitro'seed germination and shoot proliferation of galax ['Galax urceolata'(Poir.) Brummitt]. Aust J Crop Sci. 2013;7(11):1766.

19. Simlat M, Slezak P, Mos M, Warchol M, Skrzypek E, Ptak A. The effect of light quality on seed germination, seedling growth and selected biochemical properties of Stevia rebaudiana Bertoni. Scientia Horticulturae. 2016;211:295-304. doi: 10.1016/j.scienta.2016.09.009.

20. Wall WA, Hilton JL, Wentworth TR, Gray JB, Hohmann MG, Hoffmann WA. Effects of light and temperature on germination of Pyxidanthera brevifolia Wells (Diapensiaceae)1. J Torrey Botan Soc. 2010;137(4):34854. doi: 10.3159/10-ra-023.1.

21. Oh E, Yamaguchi S, Kamiya Y, Bae G, Chung WI, Choi G. Light activates the degradation of PIL5 protein to promote seed germination through gibberellin in Arabidopsis. Plant J. 2006;47(1):124-39. doi: 10.1111/j.1365-313X.2006.02773.x. [PubMed: 16740147].

22. Huh YS, Lee JK, Nam SY, Hong EY, Paek KY, Son SW. Effects of altering medium strength and sucrose concentration onin vitrogermination and seedling growth ofCypripedium macranthosSw. J Plant Biotechnol. 2016;43(1):132-7. doi: 10.5010/jpb.2016.43.1.132.

23. Papenfus HB, Naidoo D, Posta M, Finnie JF, Van Staden J. The effects of smoke derivatives on in vitro seed germination and development of the leopard orchid Ansellia africana. Plant Biol (Stuttg). 2016;18(2):28994. doi: 10.1111/plb.12374. [PubMed: 26206372].

24. Martendal CO, Bernardino MM, Pereira FD, Silva FG, De Menezes CCE, Monteiro Hara ACBA. In vitro cultivation of zygotic embryos from Murici (Byrsonima cydoniifolia A. Juss.): establishment, disinfection, and germination. Acta Scientiarum Agron. 2013;35(2). doi: 10.4025/actasciagron.v35i2.15402.

25. Priyanka S, Swati C, Anita RG, Poonam D, Jyoti R, Kavita S, et al. Effects of adenine sulphate, glutamine and casein hydrolysate on in vitro shoot multiplication and rooting of Kinnow mandarin (Citrus reticulata Blanco). Afr J Biotechnol. 2012;11(92):15852-62. doi: 10.5897/ajb12.3244.

26. Gantait S, Kundu S, Yeasmin L, Ali MN. Impact of differential levels of sodium alginate, calcium chloride and basal media on germination frequency of genetically true artificial seeds of Rauvolfia serpentina (L.) Benth. ex Kurz. J Appl Res Med Aromat Plants. 2017;4:75-81. doi: 10.1016/j.jarmap.2017.01.005. 
27. Samuel K, Debashish D, Madhumita B, Padmaja G, Prasad SR, Ramana Murthy VB, et al. In vitro germination and micropropagation of Givotia rottleriformis Griff. In Vitro Cell Dev Biol Plant. 2009;45(4):466-73. doi: 10.1007/s11627-008-9181-7.

28. Solanki P, Siwach P. Optimization of conditions for in vitro seed germination and shoot multiplication of Aconitum heterophyllum Wall. Int J Med Arom Plants. 2012;2(3):481-7.

29. Ge F, Luo X, Huang X, Zhang Y, He X, Liu M, et al. Genome-wide analysis of transcription factors involved in maize embryonic callus formation. Physiol Plant. 2016;158(4):452-62. doi: 10.1111/ppl.12470. [PubMed: 27194582].

30. Jaiswal VS, Narayan P. Regeneration of plantlets from the callus of stem segments of adult plants of Ficus religiosa L. Plant Cell Rep. 1985;4(5):256-8. doi: 10.1007/BF00269371. [PubMed: 24253982].

31. Su YH, Liu YB, Zhang XS. Auxin-cytokinin interaction regulates meristem development. Mol Plant. 2011;4(4):616-25. doi:10.1093/mp/ssr007. [PubMed: 21357646].

32. Parasharami V. Ficus religiosa L.: callus, suspension culture and lectin activity in fruits and in vitro regenerated tissues. Br Biotechnol J. 2014;4(2):215-27. doi: 10.9734/bbj/2014/7338.
33. Sundram TCM, Annuar MSM, Khalid N. Optimization of culture condition for callus induction from shoot buds for establishment of rapid growing cell suspension cultures of mango ginger ('Curcuma mangga'). Aust J Crop Sci. 2012;6(7):1139.

34. Garcia R, Pacheco G, Falcao E, Borges G, Mansur E. Influence of type of explant, plant growth regulators, salt composition of basal medium, and light on callogenesis and regeneration in Passiflora suberosa L. (Passifloraceae). Plant Cell Tissue Organ Culture. 2010;106(1):47-54. doi: 10.1007/s11240-010-9892-4.

35. Karami O, Piri K, Bahmani R. Plant regeneration through callus cultures derived from immature-cotyledon explants of oleaster (Elaeagnus angustifolia L.). Trees. 2008;23(2):335-8. doi: 10.1007/s00468-0080281-0.

36. Lavanya AR, Muthukrishnan S, MuthuKumar M, Benjamin JHF, Senthil Kumar T, Kumaresan V, et al. Indirect organogenesis from various explants of Hildegardia populifolia (Roxb.) Schott \& Endl. - A threatened tree species from Eastern Ghats of Tamil Nadu, India. J Gene Engin Biotechnol. 2014;12(2):95-101. doi 10.1016/j.jgeb.2014.09.002. 